Niepełnosprawność. Dyskursy pedagogiki specjalnej

Nr 36/2019

Disability. Discourses of special education

No. 36/2019

\title{
Beata Antoszewska
}

Uniwersytet Warmińsko-Mazurski w Olsztynie

\section{Relacja lekarz - dziecko w ocenie rodziców dzieci leczonych na oddziałach onkohematologii dziecięcej}

Artykuł prezentuje wyniki badań związane z opiniami rodziców na temat relacji nawiązywanych przez lekarzy prowadzących z pacjentami chorymi na nowotwory. Materiał badawczy zebrano przy wykorzystaniu metody sondażu diagnostycznego. Jako narzędzia użyto kwestionariusza skonstruowanego na wzór narzędzia opracowanego przez Aleksandrę Barczak i Sylwię Kołtan. Miejscem badań były trzy kliniki onkohematologii dziecięcej w Polsce należące do Polskiej Pediatrycznej Grupy ds. Leczenia Białaczek i Chłoniaków.

Analiza zgromadzonego materiału badawczego wskazuje, iż relacja lekarz - dziecko chore na nowotwór została przez rodziców oceniona pozytywnie. Obserwacja w trakcie prowadzonych wcześniej badań oraz rozmowy z rodzicami pacjentów onkologicznych wskazują na przyjazny, a w niektórych przypadkach nawet rodzinny klimat oddziałów onkohematologii dziecięcej.

Słowa klucze: choroba nowotworowa, relacja lekarz - pacjent, komunikacja

\section{Physician - child relationship as perceived by parents of children treated at Departments of Paediatric Oncology and Haematology}

This paper presents the results of research devoted to parents' opinions concerning the relationship established between attending physicians and patients treated due to cancer. The analyzed research material was collected with the use of a diagnostic survey. The survey was carried out using a questionnaire modelled on the tool designed by Aleksandra Barczak and Sylwia Kołtan. The study was conducted in three Clinics of Paediatric Oncology and Haematology in Poland that are supervised by the Polish Paediatric Leukaemia and Lymphoma Study Group.

The analysis of the collected research material indicates that parents assess the physician - cancer patient relationship positively. Observations made during earlier studies and interviews with parents of oncology patients point to a friendly, and in some cases even familial setting of Departments of Paediatric Oncology and Haematology.

Keywords: cancer, physician - patient relationship, communication. 


\section{Wprowadzenie}

Teoretyczne ujęcie problemu relacji lekarz - dziecko w polskiej literaturze przedmiotu pojawia się często i obecne jest w niej od dawna. Odmiennie natomiast kształtuje się tendencja frekwencyjności tego tematu w ujęciu empirycznym. Badacze podejmują je od niedawna i wciąż sporadycznie. Warto zauważyć, iż literatura obcojęzyczna bogata jest zarówno w prace teoretyczne, jak i empiryczne z zakresu relacji lekarz - pacjent (dziecko) (np. Aronsson, Rundström 1988; Tates, Meeuwesen, Elbers, Bensing 2002; Zwaanswijk, Tates, van Dulmen, Hoogerbrugge, Kamps, Bensing 2007; Zwaanswijk, Tates, van Dulmen, Hoogerbrugge, Kamps, Beishuizen, Bensing 2011; Blazin, Cecchini, Habashy, Kaye, Baker 2018). $\mathrm{W}$ podejmowanych pracach uczeni stosują nie tylko metodologię ilościową, lecz coraz częściej decydują się na jakościowe ujęcie badawcze, analizujące dogłębnie poruszane zjawisko.

Uwaga autorów skoncentrowana jest przede wszystkim na komunikacji (werbalnej, jak i pozawerbalnej) lekarza z pacjentem (dzieckiem) w różnym wie$\mathrm{ku}$, jego oczekiwaniach, jak również oczekiwaniach rodziców wobec personelu medycznego. Niemalże wszystkie prace wskazują, iż relacja lekarz - dziecko jest istotna $\mathrm{w}$ procesie terapeutycznym oraz profilaktyce zdrowotnej.

Jednak możliwości uczestnictwa dziecka w relacji medycznej (np. wywiadzie medycznym), jak zauważają K. Tates, L. Meeuwesen, E. Elbers, J. Bensing (2002), zależą od cech zachowania osób dorosłych. To rodzic wraz z lekarzem tworzą (lub nie) warunki pozwalające na czynny udział dziecka w konsultacji medycznej i procesie leczenia. Wcześniejsze prace, jak piszą wspomniani autorzy, mocno eksponowały rolę rodzica (lub opiekuna) jako osoby będącej najbardziej wiarygodnym źródłem informacji dla lekarza. Aktualnie coraz częściej uwaga koncentruje się na dziecku jako podmiocie mogącym uczestniczyć w relacji medycznejopowiadać o swoim samopoczuciu oraz dolegliwościach czy odpowiadać na zadawane pytania. Zrozumiałe jest, iż udział ten zależy od wieku pacjenta i poziomu jego rozwoju poznawczego. Zauważyć należy, że nawet małe dziecko o słabych możliwościach werbalizowania może lub powinno być włączone w kontakt z lekarzem (zob. np. Jankowska i in. 2010; Jankowska 2012; Antoszewska, Bohdan 2017).

Warto wspomnieć, że wyniki polskich badań związane z relacją lekarz - dziecko są zróżnicowane. Badania prowadzone przez studentów Akademii Medycznej we Wrocławiu, działających w Międzynarodowym Stowarzyszeniu Studentów Medycyny IFMSA-Poland, podczas akcji "Szpital Pluszowego Misia”, dowodzą, że znaczna część lekarzy (39\%) zawsze objaśnia dziecku wykonywane czynności oraz ich cel, $54 \%$ czyni to czasem, a tylko $7 \%$ nie robi tego w ogóle. Ponadto zdecydowana większość (68\%) lekarzy, zbierając wywiad, rozmawia również z małym pacjentem. Niemalże wszyscy respondenci badania wskazali, że wybrany przez 
nich lekarz ma przyjazny kontakt z dzieckiem (98,5\%) i nieco mniejsza grupa (93\%) lekarzy ma dla pacjenta upominek. Należy jednak zaznaczyć, iż chociaż ponad połowa (54\%) ankietowanych podkreśla indywidualne traktowanie dziecka przez lekarza, to jednak aż $41 \%$ życzyłoby sobie bardziej indywidualnego kontaktu lekarz - pacjent (Banyś i in. 2007).

Inne badania prowadzone przez zespół Małgorzaty Kazimierczak (Kazimierczak, Grzymała-Turzańska, Kobiołka 2016) w Oddziale Chirurgii Dziecięcej Gliwickiego Centrum Medycznego w 2015 roku wskazują, że dzieci wysoko oceniły serdeczność, wrażliwość personelu i jego profesjonalizm. Jednak połowa z nich nie znała tożsamości swojego lekarza i pielęgniarek oraz nie została zapoznana z prawami dziecka w szpitalu. Zdaniem autorek ocena jakości informacji uzyskanych od lekarza również nie przedstawiała się optymistycznie. Blisko jedna trzecia dzieci stwierdziła, że nikt $\mathrm{z}$ nimi nie rozmawiał lub nic nie rozumiały z prowadzonych z nimi rozmów.

Badania jakościowe z grupą chorych dzieci i ich rodziców prowadził zespół Jerzego Konstantynowicza Konstantynowicz, Marcinowicz, Abramowicz, Abramowicz, 2016). Wywiady prowadzono na terenie Kliniki Pediatrii i Zaburzeń Rozwojowych Uniwersytetu Szpitala Dziecięcego w Białymstoku, a ich celem była ocena opieki zdrowotnej realizowanej $w$ trakcie hospitalizacji, poznanie oczekiwań związanych z zachowaniem lekarzy oraz najważniejszych elementów wpływających na satysfakcję z realizowanej opieki. Wyniki wskazują, iż zarówno rodzice, jak i dzieci (pacjenci) oczekiwali od lekarzy zrozumiałych informacji na temat choroby i procesu leczenia, jednak nie zawsze je uzyskiwali. Zdaniem badanych posługiwanie się przez lekarzy żargonem medycznym $\mathrm{w}$ rozmowie z pacjentem może być celowe i służyć unikaniu szczegółowych wyjaśnień, jak również zniechęcaniu go do zadawania kolejnych pytań. Warto zauważyć jednak, że uczestnicy badań, zauważając problem w komunikacji z lekarzem, starali się jednocześnie usprawiedliwiać jego zachowania przede wszystkim brakiem czasu.

\section{Metodologia prowadzonych badań}

Jak wspomniano, zagadnienie relacji lekarz - dziecko jest w nikłym zakresie zgłębione w polskiej literaturze przedmiotu - zwłaszcza w odniesieniu do pacjenta onkologicznego. Temat zaś jest istotny, a jego właściwe rozpoznanie może wspomóc proces terapeutyczny, dlatego celem prezentowanej pracy jest poznanie relacji lekarz - pacjent (dziecko) w percepcji rodziców.

Badania, które stoją u podstaw poznania tej relacji, prowadzono w nurcie ilościowym z wykorzystaniem metody sondażu diagnostycznego, który umożliwia zbadanie określonego zjawiska społecznego, $\mathrm{w}$ tym przypadku oceny relacji dzie- 
cka chorego onkologicznie z lekarzem prowadzącym. Zastosowano kwestionariusz ankiety opracowany przez Aleksandrę Barczak i Sylwię Kołtan (2009: 96-101). Narzędzie badawcze dotyczyło zagadnienia komunikacji - zarówno werbalnej, jak i niewerbalnej (czytelności, czasu, poruszanych tematów, tonu głosu). W kwestionariuszu zawarto także zdania niedokończone związane z osobą lekarza prowadzącego. Główny problem badawczy został sformułowany następująco: Jak relację lekarz - dziecko z chorobą onkologiczną postrzegają i oceniają rodzice?

Miejscem badań były trzy kliniki onkohematologii dziecięcej w Polsce należące do Polskiej Pediatrycznej Grupy ds. Leczenia Białaczek i Chłoniaków. Prowadzenie badań na terenie klinik wymagało zgody kierowników (zgodę taką uzyskano). Ze względu jednak na konieczność zachowania anonimowości powyższych placówek, nie podano ich nazw.

W badaniu wzięło udział 45 osób, rodziców dzieci chorych na nowotwory (85\% kobiet, $\mathrm{N}=34$ i 15\% mężczyzn, $\mathrm{N}=6$ ), w wieku 30-60 lat. Większość badanych znajdowała się w grupie wiekowej $31-40$ lat $(58 \%, \mathrm{~N}=21)$ i przeważnie mieszkała w mieście $(65 \%, \mathrm{~N}=22)$.

Pod względem wykształcenia, przeważali rodzice $\mathrm{z}$ wykształceniem zawodowym $(46 \%)$, kolejną grupę stanowili rodzice z wykształceniem wyższym $(41 \%)$, rodzice z wykształceniem średnim (10\%) i z podstawowym (3\%). Zdecydowana większość uczestników badania pozostawała w związku małżeńskim (79\%). W badanej grupie nie było wdów/wdowców. W badanej grupie najwięcej rodziców $(55 \%)$ posiada dwoje dzieci, ale hospitalizowane dziecko jest ich najstarszym dzieckiem.

Większość chorych dzieci była hospitalizowana wiele razy, ale leczenie trwało krócej niż rok. Najczęściej w trakcie leczenia z dziećmi przebywają matki (78\%), natomiast zdecydowanie rzadziej ojcowie (11\%).

\section{Prezentacja wyników badań}

Zdecydowana większość rodziców (86\%) oceniła kontakt dziecka z lekarzem prowadzącym jako dobry lub bardzo dobry. Generalną pozytywną opinię rodziców na temat lekarza prowadzącego potwierdza szereg stwierdzeń jednostkowych. Osoby badane miały ustosunkować się do pytań zamkniętych zamieszczonych w kwestionariuszu, zaznaczając odpowiedź "tak" lub "nie" (a w przypadku niektórych także "czasami”). W tabeli poniżej przedstawiono częstość odpowiedzi twierdzących.

Niemalże wszyscy twierdzili, że dzieci rozumieją, co lekarz mówi. Stwierdzenie to pozwala wysunąć wniosek, iż lekarz używał zrozumiałego słownictwa lub starał się je dostosować do rozmówcy. Rodzice oceniali, że lekarze wyjaśniają, na 
czym polega choroba, i podkreślali, że lekarze zauważają zmiany w nastroju dzieci. Zwracają się do nich po imieniu, a także nawiązują z nimi kontakt wzrokowy. W relacji okazują dzieciom sympatię, zagadują je na korytarzu i często w rozmowach starają się je rozśmieszać. Badani, oceniając podejście lekarza do konkretnego dziecka, wskazywali, iż jest traktowane na równi z innymi pacjentami. Rodzice w wypowiedziach na temat zachowania lekarzy uznali, że potrafią oni pocieszyć dziecko $w$ trudnych chwilach i złagodzić jego strach przed zabiegiem. Zdecydowana większość twierdziła, że lekarze starają się pomóc dzieciom. Warto dodać, że dla pacjenta ważna jest kwestia czasu, który lekarz mu poświęca. Ponad 3/4 rodziców chciaůaby, aby lekarz poúwićcaů ich dziecku wićcej czasu.

W kwestionariuszu znajdowały się również pytania odnoszące się do oceny kontaktu lekarza z rodzicem. Uzyskane oceny dotyczące tego wymiaru relacji także w większości były pozytywne. Ponad 3/4 rodziców wskazała, że lekarze rozmawiają z nimi o chorobie i związanych z nią dolegliwościach. Często rozmowy te prowadzone są w obecności dziecka $(71 \%)$. Badani mieli poczucie, że są rozumiani przez lekarzy. W większości (56\%) uważali, że lekarz potrafi złagodzić ich strach, 53\% uznało, że lekarze widzą ich przygnębienie, a $42 \%$ wskazało, że lekarze są z nimi w trudnych chwilach. Jednak tylko $34 \%$ oceniło swój udział w podejmowanych decyzjach jako znaczący. 65\% uważa, że lekarze starają się przekonać co do słuszności podjętych terapii. Można wnioskować, iż rodzice uznają profesjonalizm i autorytet wiedzy lekarza, powierzając mu większość decyzji związanych z leczeniem. $12 \%$ badanych rodziców bało się rozmawiać z lekarzem.

Tabela 1. Zestawienie odpowiedzi twierdzących na pytania z kwestionariusza dotyczące lekarza

\begin{tabular}{|l|c|c|c|c|}
\hline \multirow{2}{*}{ Pytanie } & \multicolumn{2}{|l|}{ Odpowiedzi twierdzące } & \multicolumn{2}{l|}{ Odpowiedzi „czasem” } \\
\cline { 2 - 5 } & $\mathrm{N}$ & $\%$ & $\mathrm{~N}$ & $\%$ \\
\hline $\begin{array}{l}\text { Czy Pan/Pani ma poczucie, że zawsze może się } \\
\text { zwrócić do lekarza o pomoc? }\end{array}$ & 42 & 100 & & \\
\hline Czy dziecko rozumie, co lekarz mówi do niego? & 40 & 95 & & 2 \\
\hline Czy lekarz zwraca się do dziecka po imieniu? & 40 & 95 & 1 & \\
\hline $\begin{array}{l}\text { Czy Pan/Pani ma wrażenie, że lekarz zawsze } \\
\text { stara się dziecku pomóc? }\end{array}$ & 40 & 95 & & 10 \\
\hline $\begin{array}{l}\text { Czy Pan/Pani ma poczucie, że dziecko jest } \\
\text { traktowane przez lekarza na równi z innymi } \\
\text { pacjentami? }\end{array}$ & 36 & 86 & 4 & 7 \\
\hline Czy lekarz okazuje dziecku sympatię? & 36 & 86 & 3 & 7 \\
\hline $\begin{array}{l}\text { Czy lekarz nawiązuje kontakt wzrokowy } \\
\text { z dzieckiem? }\end{array}$ & 36 & 86 & 4 & \\
\hline
\end{tabular}




\begin{tabular}{|c|c|c|c|c|}
\hline $\begin{array}{l}\text { Czy Pan/Pani uważa, że lekarz na Pana/Pani } \\
\text { prośbę jest dyskretny? }\end{array}$ & 34 & 81 & 4 & 10 \\
\hline $\begin{array}{l}\text { Czy lekarz często rozmawia z Pania/Panem } \\
\text { o dolegliwościach dziecka? }\end{array}$ & 33 & 79 & & \\
\hline Czy lekarz zauważa przygnębienie dziecka? & 31 & 80 & & \\
\hline Czy lekarz potrafi rozśmieszyć dziecko? & 30 & 75 & & \\
\hline $\begin{array}{l}\text { Czy chciałby Pan/Pani, aby lekarz poświęcał } \\
\text { dziecku więcej czasu? }\end{array}$ & 30 & 77 & & \\
\hline $\begin{array}{l}\text { Czy lekarz często rozmawia z dzieckiem } \\
\text { o dolegliwościach? }\end{array}$ & 30 & 70 & & \\
\hline $\begin{array}{l}\text { Czy lekarz tłumaczył dziecku, na czym polega } \\
\text { choroba? }\end{array}$ & 30 & 71 & & \\
\hline $\begin{array}{l}\text { Czy lekarz czasem zagaduje dziecko } \\
\text { na korytarzu? }\end{array}$ & 29 & 67 & & \\
\hline $\begin{array}{l}\text { Czy lekarz rozmawia z Panem/Panią } \\
\text { w obecności dziecka o jego chorobie? }\end{array}$ & 29 & 71 & & \\
\hline $\begin{array}{l}\text { Czy podczas rozmowy z lekarzem ma Pan/ } \\
\text { Pani poczucie, że lekarz Pana/Panią rozumie? }\end{array}$ & 29 & 67 & 11 & 26 \\
\hline $\begin{array}{l}\text { Czy lekarz potrafi złagodzić strach dziecka } \\
\text { przez zabiegiem? }\end{array}$ & 28 & 65 & 7 & 16 \\
\hline Czy lekarz potrafi pocieszyć dziecko? & 28 & 65 & 12 & 28 \\
\hline $\begin{array}{l}\text { Czy lekarz pyta Pana/Panią o ogólne samo- } \\
\text { poczucie dziecka na oddziale? }\end{array}$ & 26 & 62 & & \\
\hline $\begin{array}{l}\text { Czy lekarz próbuje przekonać Pana/Panią } \\
\text { do podjętej terapii? }\end{array}$ & 26 & 65 & 4 & 10 \\
\hline $\begin{array}{l}\text { Czy lekarz potrafi złagodzić Pana/Pani } \\
\text { strach przed zabiegiem? }\end{array}$ & 24 & 56 & 10 & 23 \\
\hline Czy lekarz zauważa Pani/Pana przygnębienie? & 21 & 53 & & \\
\hline $\begin{array}{l}\text { Czy lekarz jest z Panią/Panem w trudnych } \\
\text { chwilach? }\end{array}$ & 16 & 42 & 13 & 34 \\
\hline $\begin{array}{l}\text { Czy Pan/Pani ma wpływ na podejmowane } \\
\text { przez lekarza decyzje? }\end{array}$ & 14 & 34 & 12 & 29 \\
\hline $\begin{array}{l}\text { Czy lekarz pyta Pana/Panią o sprawy nie- } \\
\text { związane bezpośrednio z chorobą dziecka? }\end{array}$ & 12 & 29 & & \\
\hline Czy Pani/Pan boi się rozmawiać z lekarzem? & 5 & 12 & & \\
\hline
\end{tabular}

Źródło: opracowanie własne. 


\section{Ocena lekarza według rodziców z uwzględnieniem wpływu wybranych zmiennych}

Porównano ocenę lekarzy przez rodziców ze względu na wybrane zmienne. Analizowano szereg stwierdzeń, do których rodzice mieli ustosunkować się twierdząco bądź przecząco (poza stwierdzeniem „Czy Pan/Pani ma poczucie, że zawsze może się zwrócić do lekarza o pomoc?", gdzie 100\% uczestników udzieliło odpowiedzi twierdzącej).

Pod uwagę wzięto takie zmienne, takie jak miejsce zamieszkania, wykształcenie oraz długość leczenia dziecka. Czynniki, takie jak wiek, płeć oraz osoba sprawująca opiekę nad dzieckiem nie mogły być użyte do porównań, ze względu na zbyt duże różnice w liczebności osób. Wszystkie analizy przeprowadzono z użyciem testu Chi kwadrat.

\section{Miejsce zamieszkania}

Odnotowano jedną istotną różnicę oraz jedną różnicę na poziomie tendencji ze względu na miejsce zamieszkania. Rodzice w większości zgadzali się, że lekarz jest dyskretny, ale więcej mieszkańców miast nie podzielało tej opinii. Z kolei mieszkańcy wsi częściej zaznaczali odpowiedź "czasami”, Chi ${ }^{2}=9,24, \mathrm{p}=0,01$, $\mathrm{V}=0,54$. Różnice ilustruje wykres 1 .

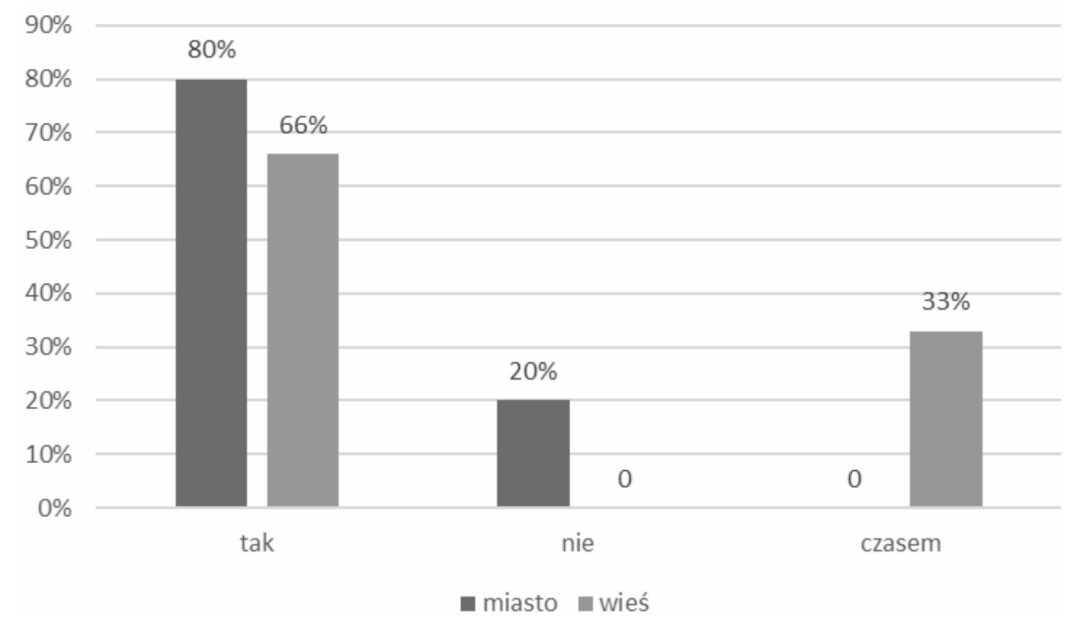

Wykres 1. Rozkład odpowiedzi na pytanie „Czy Pan/Pani uważa, że lekarz na Pana/Pani prośbę jest dyskretny?” w zależności od miejsca zamieszkania Źródło: opracowanie własne. 
Ponadto zaobserwowano różnicę na poziomie tendencji $\mathrm{w}$ ocenie pytań niezwiązanych bezpośrednio $\mathrm{z}$ chorobą, $\mathrm{Chi}^{2}=5,41, \mathrm{p}=0,07, \mathrm{~V}=0,42$. Rodzice z miast częściej deklarowali występowanie takich pytań niż rodzice ze wsi. Różnice ilustruje wykres 2.

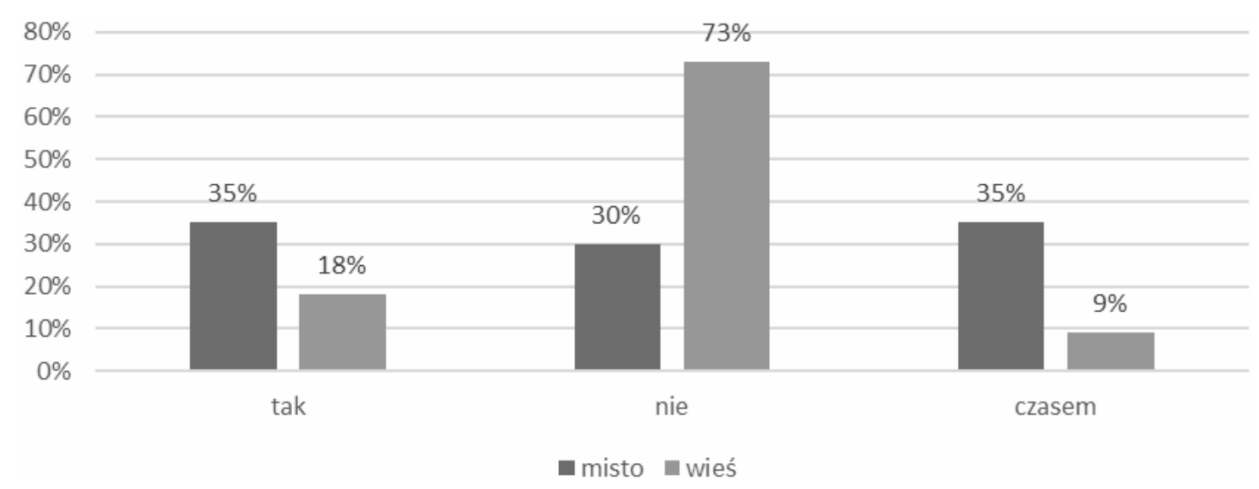

Wykres 2. Rozkład odpowiedzi na pytanie „Czy lekarz pyta Pana/Panią o sprawy niezwiązane bezpośrednio z chorobą?” w zależności od miejsca zamieszkania.

Źródło: opracowanie własne.

Dla pozostałych ocen lekarza nie uzyskano różnic istotnych statystycznie.

\section{Wykształcenie}

Porównano jedynie osoby z wykształceniem wyższym $(\mathrm{N}=16)$ oraz zawodowym $(\mathrm{N}=18)$. Pozostałe osoby wykluczono $\mathrm{z}$ analiz ze względu na znikomą liczebność (4 osoby z wykształceniem średnim i 1 osoba z wykształceniem podstawowym).

Uzyskano istotne różnice $\mathrm{w}$ ocenie wpływu na podejmowane przez lekarza decyzje, $\mathrm{Chi}^{2}=7,39, \mathrm{p}=0,03, \mathrm{~V}=0,49$. Rodzice $\mathrm{z}$ wykształceniem zawodowym mieli większe poczucie wpływu na decyzje lekarza niż rodzice z wykształceniem wyższym (wykres 3).

Uzyskano także dwie różnice na poziomie tendencji: w ocenie pytań lekarza niezwiązanych bezpośrednio $\mathrm{z}$ chorobą oraz $\mathrm{w}$ ocenie możliwości złagodzenia strachu dziecka przed zabiegiem. Rodzice $\mathrm{z}$ wykształceniem zawodowym częściej deklarowali występowanie takich pytań niż rodzice z wykształceniem wyższym, $\mathrm{Chi}^{2}=5,46, \mathrm{p}=0,07, \mathrm{~V}=0,42$.

Większy odsetek rodziców z wykształceniem zawodowym negatywnie oceniał możliwość złagodzenia strachu dziecka przez lekarza, $\mathrm{Chi}^{2}=5,27, \mathrm{p}=0,07$, $\mathrm{V}=0,41$. Szczegóły przedstawiono na wykresach poniżej. 


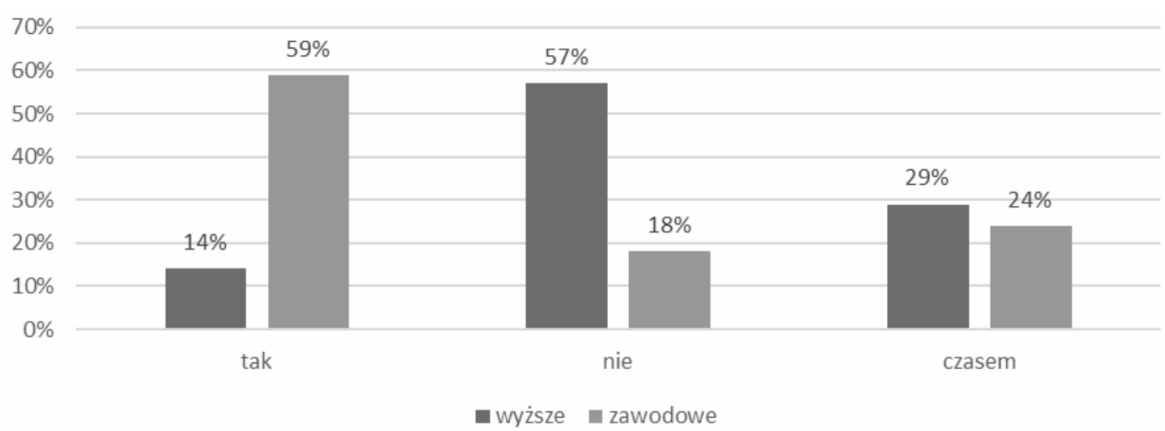

Wykres 3. Rozkład odpowiedzi na pytanie „Czy ma Pani/Pan wpływ na podejmowane przez lekarza decyzje?” w zależności od wykształcenia.

Źródło: opracowanie własne.

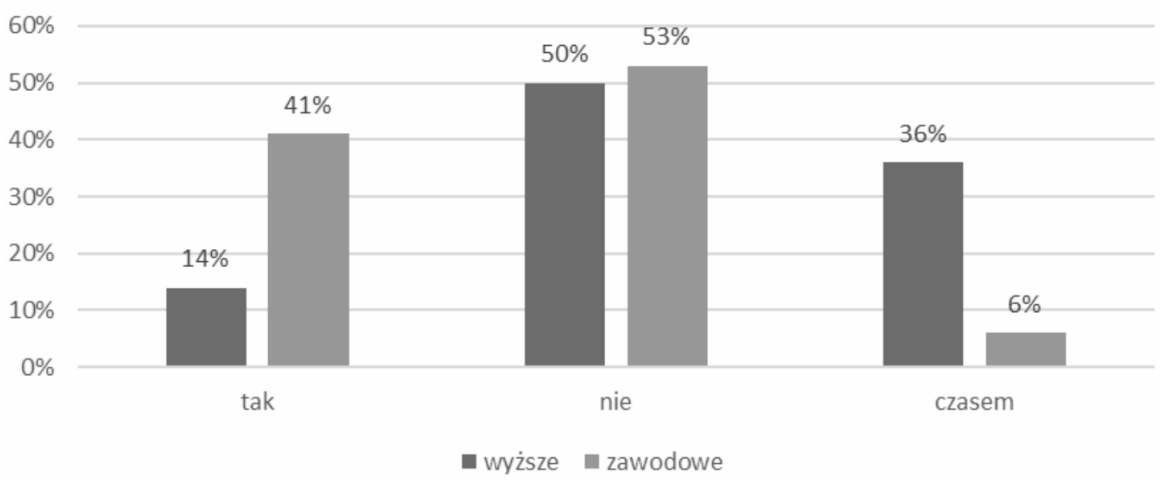

Wykres 4. Rozkład odpowiedzi na pytanie „Czy lekarz pyta Pana/Panią o sprawy niezwiązane bezpośrednio z chorobą?" w zależności od wykształcenia.

Źródło: opracowanie własne.

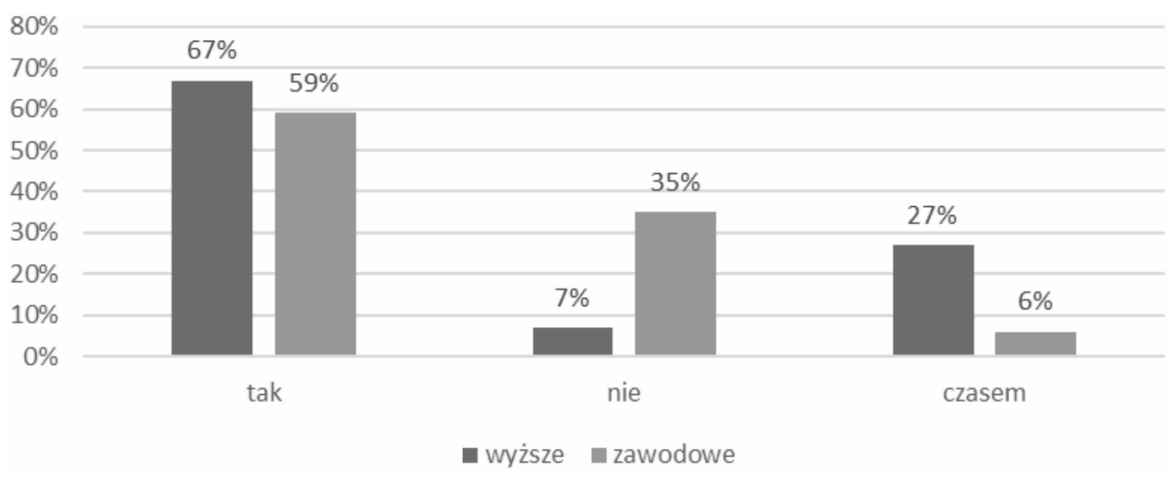

Wykres 5. Różnice w odpowiedziach na pytanie „Czy lekarz potrafi złagodzić strach dziecka przez zabiegiem?” w zależności od wykształcenia.

Źródło: opracowanie własne. 
Dla pozostałych ocen lekarza nie uzyskano różnic istotnych statystycznie.

\section{Długość leczenia}

Odnotowano dwie istotne różnice oraz jedną różnicę na poziomie tendencji ze względu na długość leczenia. Rodzice, których dzieci leczyły się rok oraz powyżej dwóch lat, istotnie częściej deklarowali swój wpływ na leczenie, $\mathrm{Chi}^{2}=19,24$, $\mathrm{p}=0,04, \mathrm{~V}=0,52$. Druga istotna różnica dotyczyła możliwości złagodzenia strachu dziecka przed zabiegiem, $\mathrm{Chi}^{2}=21,86, \mathrm{p}=0,02, \mathrm{~V}=0,54$. Więcej rodziców dzieci leczonych rok i powyżej dwóch lat deklarowała, że lekarz potrafi złagodzić lęki dziecka.

Różnica na poziomie tendencji dotyczyła czasu poświęcanego dziecku, $\mathrm{Chi}^{2}=$ $10,48, p=0,06, V=0,56$. Rodzice, których dzieci leczyły się dłużej, w większym odsetku deklarowali, że chcieliby, żeby lekarz poświęcał więcej uwagi dziecku (poza przypadkiem dzieci leczonych poniżej roku).

\section{Opinia o lekarzu}

Badani rodzice w różny sposób formułowali zakończenie zdania: „Lekarz mojego dziecka jest...". Warto wskazać, iż przeważały przede wszystkim cechy osobowościowe związane z dociekliwością i byciem miłym (30\%, N=10), a także ogólnie pozytywna opinia - jest "ok" (18\%, N=6). Za cechy najbardziej pożądane i cenione u lekarzy rodzice uznali lekarski profesjonalizm i wrażliwość $(48 \%, \mathrm{~N}=13)$. $43 \%$ rodziców chciałoby, żeby lekarz poświęcał więcej uwagi dziecku $(\mathrm{N}=9)$, ale zbliżona liczba badanych deklaruje, iż nie chce, aby lekarz się zmieniał (33\%, $\mathrm{N}=7$ ). Szczegółowe odpowiedzi przedstawiono w tabelach poniżej.

Tabela 2. Rozkład odpowiedzi rodziców na zdanie niedokończone: „Lekarz mojego dziecka..."

\begin{tabular}{|l|c|c|}
\hline \multicolumn{1}{|c|}{ Lekarz mojego dziecka jest... } & N & $\%$ \\
\hline dociekliwy i miły & 10 & 30,3 \\
\hline ok & 6 & 18,2 \\
\hline specjalistą & 5 & 15,2 \\
\hline lekarzem z powołania & 3 & 9,1 \\
\hline kobietą/mężczyzną & 2 & 6,1 \\
\hline imię i nazwisko & 2 & 4,4 \\
\hline
\end{tabular}




\begin{tabular}{|l|c|c|}
\hline \multicolumn{1}{|c|}{ Lekarz mojego dziecka jest... } & N & $\%$ \\
\hline skromny i uprzejmy & 2 & 3,0 \\
\hline dziwny & 1 & 3,0 \\
\hline mądrym człowiekiem & 1 & 3,0 \\
\hline zaangażowany & 1 & 100,0 \\
\hline Ogółem & 33 & \\
\hline
\end{tabular}

Źródło: opracowanie własne.

Tabela 3. Rozkład odpowiedzi rodziców na zdanie niedokończone: „Najbardziej cenią lekarza za..."

\begin{tabular}{|l|c|c|}
\hline \multicolumn{1}{|c|}{ Najbardziej cenię lekarza za... } & N & $\%$ \\
\hline pracę: profesjonalizm, wrażliwość & 13 & 48,1 \\
\hline dobre podejście & 7 & 25,9 \\
\hline szczerość & 3 & 11,1 \\
\hline uśmiech & 2 & 7,4 \\
\hline opanowanie & 1 & 2,2 \\
\hline dyskrecję & 1 & 3,7 \\
\hline Ogółem & 27 & 100,0 \\
\hline
\end{tabular}

Źródło: opracowanie własne.

Tabela 4. Rozkład odpowiedzi rodziców na zdanie niedokończone „Chciałbym, aby lekarz mojego dziecka..."

\begin{tabular}{|l|c|c|}
\hline \multicolumn{1}{|c|}{ Chciałbym, aby lekarz mojego dziecka... } & N & $\%$ \\
\hline poświęcał więcej uwagi & 9 & 42,9 \\
\hline nie zmieniał się & 7 & 33,3 \\
\hline był bardziej rozmowny & 3 & 14,3 \\
\hline mógł zrobić więcej & 2 & 9,5 \\
\hline Ogółem & 21 & 100 \\
\hline
\end{tabular}

Źródło: opracowanie własne.

Należy podkreślić (choć tu sporadycznie uzyskano odpowiedzi), że rodzice nie dostrzegają u lekarzy cech, które najmniej im się podobają. Wśród odpowiedzi znalazły się niewłaściwe podejście do dziecka i roztargnienie lekarza. Szczegóły przedstawiono w tabeli 5 . 
Tabela 5. Rozkład odpowiedzi rodziców na zdanie niedokończone „Najmniej podoba mi się w lekarzu..."

\begin{tabular}{|l|l|c|}
\hline \multicolumn{1}{|c|}{ Najmniej podoba mi się w lekarzu... } & N & $\%$ \\
\hline podejście do dziecka & 2 & 22,2 \\
\hline Roztargnienie & 2 & 55,6 \\
\hline małe doświadczenie & 1 & 11,1 \\
\hline słaba komunikacja & 1 & 11,1 \\
\hline brak samodzielności w podejmowaniu decyzji & 1 & 44,4 \\
\hline brak wyrozumiałości & 1 & 77,8 \\
\hline Porywczość & 1 & 88,9 \\
\hline Ogółem & 9 & 100 \\
\hline
\end{tabular}

Źródło: opracowanie własne.

\section{Podsumowanie}

W specjalistycznej opiece pediatrycznej istotne są opinie i zadowolenie pacjentów, jak również ich rodziców (czy prawnych opiekunów) (Konstantynowicz, Marcinowicz, Abramowicz, Abramowicz 2016). Pozwalają one dostrzec obszary najbardziej „zaniedbane” $\mathrm{w}$ opiece, tworząc szansę na zmianę. Ponadto dzięki stałemu monitorowaniu opinii osób korzystających ze świadczeń zdrowotnych można podnosić ich jakość. Przeprowadzone analizy mogą być pomocne w przygotowywaniu studentów medycyny do skutecznego, ale równocześnie satysfakcjonującego komunikowania się z pacjentami pediatrycznymi i ich opiekunami.

Wagę podjętego w tekście zagadnienia podkreślają L. Marcinowicz, J. Konstantynowicz, S. Chlabicz (2008), którzy piszą, iż łatwiej jest poprawić ogólną dostępność do usług opieki zdrowotnej, niż zmienić relację lekarz - pacjent, ukształtowaną przez osobiste cechy i zachowania ekspresyjne lekarza. Pominięcie głosu pacjenta i/lub jego rodziny, stanowiących integralną część zespołu opieki zdrowotnej, przyczynia się do rezygnacji z cennego źródła informacji o potrzebach i ocenie opieki zdrowotnej, a tym samym uniemożliwia zmiany.

Analiza zgromadzonego materiału badawczego wskazuje, iż relacja lekarz dziecko chore na nowotwór została przez rodziców oceniona pozytywnie. Wyniki odbiegają od najczęściej wyrażanych przez pacjentów opinii, w których dominuje negatywna ocena relacji lekarz - pacjent. Zdecydowanie częściej słyszy się wiele krytycznych uwag, opinii o braku satysfakcji z uzyskiwanych świadczeń i skarg wysuwanych pod adresem białego personelu. Obserwacja w trakcie prowadzonych wcześniej badań oraz rozmowy z rodzicami pacjentów onkologicznych wskazują na przyjazny, a w niektórych przypadkach nawet rodzinny klimat 
oddziałów onkohematologii dziecięcej. Należy zauważyć, iż sprzyjać temu może przyjęta $\mathrm{w}$ onkohematologii zasada sprawowania opieki nad dzieckiem przez jednego lub dwóch lekarzy prowadzących. Sytuacja taka służy wytworzeniu innej - osobowej więzi zarówno z dzieckiem, jak i jego rodzicami (opiekunami). Warto także podkreślić, iż opinie dzieci chorych na nowotwory związane z relacją lekarz - pacjent, będące przedmiotem uwagi innych autorów (Barczak, Kołtan 2009; Antoszewska, Tobota 2018), są zbieżne z uzyskanymi w przedstawionych badaniach.

Wyniki badań wskazują, że pacjenci onkologiczni oraz ich rodzice są informowani o chorobie i włączani w proces wyboru podjętych terapii. Darzą lekarzy prowadzących zaufaniem i mają poczucie traktowania na równi z innymi pacjentami. Można przypuszczać, iż lekarze biorą pod uwagę rozmaite czynniki składające się na optymalną relację. M. Motyka (2002) wymieniał tu czynniki mające charakter głównie informacyjny (zbieranie informacji, udzielanie informacji, wyjaśnianie, udzielanie rad i zaleceń) oraz emocjonalny i wspierający (pocieszanie i uspokajanie, okazywanie ciepła, empatia). W leczeniu choroby nowotworowej pacjentów pediatrycznych zaufanie, jakim rodzice darzą lekarza, ma bardzo duże znaczenie. Ważne jest również, aby rodzice mogli obserwować zaangażowanie lekarza w nawiązanie i utrzymywanie kontaktu z pacjentem, bowiem ono sprzyja współpracy, jak również podnosi satysfakcję z uzyskiwanej pomocy. Badani rodzice w większości uznali, iż lekarz pociesza i uspokaja dziecko w sytuacjach trudnych. Co więcej wskazali, iż sami także odczuwają wsparcie lekarzy. Jest to istotny aspekt budowania relacji, zwłaszcza że, jak wskazują I. Carey, B. Nicholson oraz R. Fox (2002), rodzice mają potrzebę podzielenia się swoimi emocjami i przeżyciami z osobami spoza rodziny.

\section{Bibliografia}

Antoszewska B., Bohdan Z. (2017), Dialog w "trójkacie porozumienia”: relacja lekarz - dziecko rodzice w sytuacji choroby przewlektej. Aspekty praktyczne, Psychoonkologia, 21 (4), 142-148.

Antoszewska B., Tobota A. (2019), Relacja z lekarzem w opiniach dzieci i młodzieży hospitalizowanych z powodu choroby nowotworowej, Człowiek - Niepełnosprawność - Społeczeństwo, 2(44), 99-110.

Aronsson K., Rundstrom B. (1988), Child discourse and parental control in pediatric consultation, Spec. Med. 26, 159-189.

Banyś M., Drożdż A., Wiszniowska M., Pawlas K., Brużewicz S. (2007), Lekarze pierwszego kontaktu w ocenie rodziców dzieci w wieku przedszkolnym, Family Medicine \& Primary Care Review, 9(2), 204-208.

Barczak A., Kołtan S. (2009), Ocena relacji między pacjentami pediatrycznymi leczonymi z powodu choroby nowotworowej a ich lekarzami prowadzacymi, Onkologia Polska, 2, 96-101. 
Blazin L.J., Cecchini C., Habashy C., Kaye E., Baker J.N. (2018), Communicating Effectively in Pediatric Cancer Care: Translating Evidence into Practice, Children 5(3), 40, 3-16.

Carey I., Nicholson B., Fox R. (2002), Maternal factors related to parenting young children with congenital heart disease, Journal of Pediatric Nursing, 17, 174-183.

Jankowska A.K. (2012), Postępowanie z dzieckiem i jego opiekunami. Porozumiewanie się z nastolatkiem [w:] A. Steciwko, J. Barański (red.), Porozumiewanie się lekarza z pacjentem i jego rodzina, Wydawnictwo Elsevier, Wrocław.

Jankowska A.K., Grześk E., Kubica A., Koziński M., Grąbczewska Z. (2010), Specyfika wspótpracy lekarz - pacjent w pediatrii, Folia Cardiologica Excerpta, 5(2), 74-77.

Kazimierczak M., Grzymała-Turzańska B., Kobiołka A. (2016), Specyfika opieki nad nieletnim pacjentem $w$ oddziale chirurgii dziecięcej, Pielęgniarstwo Polskie, 3(61), 403-414.

Konstantynowicz J., Marcinowicz L., Abramowicz P., Abramowicz M. (2016), What do children with chronic diseases and their parents think about padiatricians? A qualitive interview study, Maternal and Child Health, 20, 1745-1752.

Marcinowicz L., Konstantynowicz J., Chlabicz S. (2008), The patient's view of the acceptability of the primary care in Poland, International Journal for Quality in Health care, 20(4), 277-283.

Motyka M. (2002), Psychoterapia elementarna w opiece ogólnomedycznej, Wydawnictwo Uniwersytetu Jagiellońskiego, Kraków.

Tates K., Meeuwesen L., Elbers E., Bensing J. (2002), I've come for his throat': roles and identities in doctor - patient-child communication, Child: Care, Health and Development, 28(1), 109-116.

Tates K., Elbers E., Meeuwesen L., Bensing J. (2002), Doctor - patient-child relationships: a 'pas de trois', Patient Education and Counseling, 48(1), 5-14.

Zwaanswijk M., Tates K., van Dulmen S., Hoogerbrugge P.M., Kamps W. A., Beishuizen A., Bensing J.M. (2007), Young patients', parents' and survivors' consultation in paediatric oncology: Results of online focus groups, BMC Pediatrics, 7, 35, 1-10.

Zwaanswijk M., Tates K., van Dulmen S., Hoogerbrugge P.M., Kamps W.A., Beishuizen A., Bensing J.M. (2011), Communicating with young patients in pediatric oncology consultations: a vignette study on child patients', parents', and survivors' communication preferences, Psycho-Oncology, 20, 269-277. 